\title{
Biocompatibility of Sealers Used in Apical Surgery: A Histological Study in Rat Subcutaneous Tissue
}

\author{
Suely Aparecida CUNHA ${ }^{1}$ \\ Fuad Jacob Abi RACHED JR ${ }^{1}$ \\ Edson ALFREDO ${ }^{1}$ \\ Jorge Esquiche LEÓN ${ }^{1}$ \\ Danyel Elias da Cruz PEREZ ${ }^{2}$ \\ ${ }^{1}$ Dental School, UNAERP - University of Ribeirão Preto, Ribeirão Preto, SP, Brazil \\ ${ }^{2}$ Department of Clinical and Preventive Dentistry, Oral Pathology Unit, \\ UFPE - Federal University of Pernambuco, Recife, PE, Brazil
}

\begin{abstract}
The aim of this study was to evaluate the biocompatibility of sealers used in apical surgery in rat subcutaneous tissue. Sterile polyethylene tubes were filled with the following sealers: Sealapex, Sealapex with addition of zinc oxide, Sealer 26 , Sealer 26 with thicker consistency (greater powder-to-resin ratio) and White MTA. The tubes were implanted in the dorsum of male rats and after 7 , 21 and 42 days, the animals were killed, obtaining 5 specimens for each sealer in each evaluation period. The lateral surface of the tube was used as negative control. The inflammatory reaction to contact with the sealers was classified as absent, mild, moderate and severe. At 7 days, all sealers caused similar inflammatory reactions in the connective tissue of the animals, with most specimens presenting a moderate to intense chronic inflammatory reaction, with presence of multinucleated giant cells. At 21 days, Sealer 26 and Sealer 26 with thicker consistency presented more intense inflammatory reaction $(\mathrm{p}=0.004)$, whereas after 42 days, the inflammatory reaction ranged from absent to mild with statistically similar results for both materials $(\mathrm{p}=0.08)$. Except for MTA, all sealers presented foreignbody granulomatous reaction at 42 days. All sealers but Sealapex presented a statistically significant decrease of the inflammatory reaction over time. In conclusion, all sealers caused moderate to severe inflammation in the earlier evaluation period. However, Sealer 26 and Sealer 26 with thicker consistency caused more intense inflammatory reactions after 21 days of contact with the tissues and no granulomatous reaction was observed for MTA at the final period of analysis.
\end{abstract}

Key Words: biocompatibility, MTA, Sealapex, zinc oxide, Sealer 26.

\section{INTRODUCTION}

Endodontic surgery is indicated in cases where the conventional endodontic retreatment is not viable, either due to a physical barrier or when the complexity of the root canal system prevents adequate disinfection (1). Because of close contact between the root-end filling material and the periapical tissues, it is important to know the biological compatibility of these sealers (1-3). Moreover, a periapical tissue injury caused by root canal sealers should be considered in case of overfilling (4).

Several materials have been used in root-end filling, namely amalgam, gutta-percha, zinc oxideeugenol-based sealers, calcium hydroxide-based sealers, glass ionomer cements, composite resin and mineral trioxide aggregate (MTA) $(2,3,5)$.

Sealapex, a calcium hydroxide-based root canal sealer, can also be used as root-end filling material. However, in order to provide better consistency and facilitate the clinical use, it is recommended the incorporation of zinc oxide $(\mathrm{ZnO})$ during mixing of the sealer (2). Although there is little evidence, this combination seems to promote periapical bone repair when used for retrograde fillings (2). Sealer 26 is an epoxy resin-based endodontic sealer that presents bismuth oxide and calcium hydroxide in its formulation. A greater powder-to-resin ratio is used to obtain a thicker consistency of this sealer for use in retrograde fillings (2). However, data regarding the biocompatibility of this sealer used with thicker consistency in retrograde

Correspondence: Dr. Danyel Elias da Cruz Perez, Curso de Odontologia, Área de Patologia Oral, Universidade Federal de Pernambuco, Avenida Prof. Moraes Rego, 1235, Cidade Universitária, 50670-901 Recife, PE, Brasil. Tel: +55-81-2126-7510. Fax: +55-81-2126-8338 e-mail: perezdec2003@yahoo.com.br 
fillings are still scarce (2).

MTA is a material that has been used for sealing of pathological or iatrogenic root perforations as well as in endodontic surgeries (5). Previous research studies and literature reviews $(1,3)$ have shown a good biological behavior of MTA, although Herrero de Morais et al. (8) have not found similar results.

It is thus necessary to evaluate and compare the potential irritability of these sealers either mixed according to the manufacturers's instructions or added of substances to increase their consistency and thickness for retrofillings, which are constantly used in daily clinical practice. Moreover, it would be interesting to compare these sealers with MTA, which is a material recommended for filling of root-end cavities. The aim of this study was to evaluate the biocompatibility of the sealers Sealapex, Sealapex with addition of $\mathrm{ZnO}$, Sealer 26, Sealer 26 with thicker consistency (greater powder-to-resin ratio) and white MTA in rat subcutaneous connective tissues.

\section{MATERIAL AND METHODS}

This study was approved by the Animal Ethics Committee of the University of Ribeirão Preto, Brazil (Protocol number 136/09). All ethical principles for use of laboratory animals were observed during the course of the study. The sealers evaluated in the study were the Sealapex (Kerr Corporation, Romulus, MI, USA), Sealapex with addition of $\mathrm{ZnO}$ (Biodinâmica, Ibiporã, PR, Brazil), Sealer 26 (Dentsply Ind. e Com. Ltda., Petrópolis, RJ, Brazil), Sealer 26 with thicker consistency and White MTA (Angelus Indústria de Produtos Odontológicos Ltda., Londrina, PR, Brazil).

In order to standardize the amount of resin used for preparation of Sealer $26,2 \mathrm{~cm}$ of resin were weighed five consecutive times in a precision balance (Ohaus Corporation, New Jersey, NJ, USA), establishing an average of $0.1685 \mathrm{~g}$. Subsequently, it was used an amount of powder sufficient to obtain a consistency sufficient to lift the sealer with a spatula at a height from 1.5 to $2.5 \mathrm{~cm}$. The powder incorporated to the resin was initially released with the aid of a dispenser to remain the referential and further standardization of the amount of powder to be used. From this referential (about $0.1 \mathrm{~g}$ ), 5 measurements of the powder were made in the same precision balance, establishing an average of $0.1258 \mathrm{~g}$.

Sealer 26 with thicker consistency was prepared by progressively incorporating approximately twice the amount of powder to the resin until a thick paste was obtained. The powder was incorporated into the resin using a flexible spatula number 24 (Duflex; SS White, Rio de Janeiro, RJ, Brazil), under vigorous mixing, in a restricted area of the glass plate. Five measurements of the powder were made in the same precision balance, establishing an average of $0.2472 \mathrm{~g}$.

Sealapex and white MTA were mixed according to the manufacturer's recommendation. The same procedure used for Sealer 26 were used to standardize the amount of $\mathrm{ZnO}$ added to Sealapex. Thus, 5 measurements of the powder were made in the same precision balance, establishing an average of $0.1555 \mathrm{~g}$.

Male adult Wistar rats (Rattus novergicus, albinus) weighing between $200 \mathrm{~g}$ and $250 \mathrm{~g}$ were used. The animals were kept in an acclimatized room (21$23^{\circ} \mathrm{C}$ ) and received a balanced diet and water ad libitum. In preparation for the experimental procedures, the animals were anesthetized by intramuscular injection of ketamine hydrochloride $(0.1 \mathrm{mg} / \mathrm{mL})$ in combination with xylazine hydrochloride $(0.05 \mathrm{mg} / \mathrm{mL})$, followed by shaving of dorsal fur, asepsis, incision and divulsion of the subcutaneous tissue to insert the test material. To implant the root canal sealer into the rat subcutaneous tissues, sterile polyethylene tubes $(1.2 \mathrm{~mm}$ diameter x $0.8 \mathrm{~mm}$ inner diameter x $10 \mathrm{~mm}$ long) were used. One of the tube end of the tubes was closed by heat to prevent the sealer from extruding. The polyethylene tubes were filled with freshly mixed sealers using a paper point with diameter compatible with that of the polyethylene tubes. Care was taken to avoid void and bubble formation and sealer overflowing. The tubes containing the sealers were immediately implanted in the subcutaneous tissue in the dorsum of the rats. The surgical wounds were adequately sutured.

The animals were euthanized at experimental periods of 7, 21 and 42 days and the regions containing the polyethylene tubes were removed. For each experimental group there were 5 specimens. The connective tissue response along the lateral wall outside of the polyethylene tubes in all specimens served as a negative control. The specimens were fixed in $10 \%$ buffered formalin solution for $24 \mathrm{~h}$ and processed for conventional histological examination.

The connective tissue adjacent to the open end of each tube was examined in 5- $\mu$ m-thick histological sections stained with hematoxylin and eosin to evaluate the presence or absence of neutrophil leukocytes, macrophages, lymphocytes, plasma cells, giant foreign body cells, dispersed material, dystrophic calcification 
and necrotic tissue. Depending on these features, the inflammatory reaction of the connective tissue was classified as absent, mild, moderate and severe (4). Initially, a descriptive analysis of the results was carried out, identifying the number of specimens according to the occurrence of each event analyzed. From this descriptive analysis, scores were attributed according to the intensity of inflammation, as follow: absent (score 1), mild (score 2), moderate (score 3) and severe (score 4).

After assigning scores, Kruskal-Wallis and Dunn's multiple-comparison tests were used to verify the existence of a statistically significant difference among the sealers, using GraphPad InStat (GraphPad Software Inc., San Diego, CA, USA) statistical software. The significance level was set at 5\%.

\section{RESULTS}

In the negative control (tissue response along the lateral wall outside the polyethylene tubes), it was possible to observe a thin layer of connective tissue, without inflammatory reaction between the tube wall and the adjacent tissue in all specimens and in all study periods. The connective tissue adjacent to the open end of the polyethylene tube was evaluated, and a descriptive analysis of the histological findings was made. The original scores attributed in accordance with the intensity of the inflammatory reaction are presented in Table 1.

\section{Days}

Sealapex. There was a moderate to severe chronic inflammatory reaction, formed predominantly by lymphocytes and macrophages, although 1 specimen presented mild inflammation. Residual sealer and foci of necrosis were observed in 1 specimen.

Sealapex with addition of $\mathrm{ZnO}$. Most specimens presented a severe chronic inflammation, with predominance of lymphocytes and macrophages. In 3 animals, foreign-body multinucleated giant cells were observed, in addition to foci of necrosis. Residual sealer was found in all specimens (Fig. 1).

Sealer 26. In most specimens, the connective tissue presented a severe chronic inflammation, predominantly formed by lymphocytes and macrophages, with presence of residual material in all specimens. In 1 animal, plasma cells were also observed.

Sealer 26 with thicker consistency. Granulation tissue with a severe chronic inflammatory reaction, mainly composed by lymphocytes and macrophages, was observed in all specimens, as well as foreign-body giant cells and residual material (Fig. 2). In 1 specimen, necrosis was also noted.

White MTA. In the experimental period, the animals showed a moderate to severe chronic inflammatory reaction, with presence of foreign-body giant cells in 1 specimen and foci of necrosis in other 2 animals. Residual sealer was often observed.

\section{Days}

Sealapex. Most specimens presented a mild chronic inflammatory reaction. Small amount of residual sealer was observed in all specimens. Foreign-body giant

Table 1. Original inflammatory scores attributed to the sealers in each rat (R) killed at each experimental period.

\begin{tabular}{|c|c|c|c|c|c|c|c|c|c|c|c|c|c|c|c|}
\hline \multirow{2}{*}{ Groups } & \multicolumn{5}{|c|}{7 days } & \multicolumn{5}{|c|}{21 days } & \multicolumn{5}{|c|}{42 days } \\
\hline & $\mathrm{R} 1$ & $\mathrm{R} 2$ & $\mathrm{R} 3$ & $\mathrm{R} 4$ & R5 & $\mathrm{R} 1$ & $\mathrm{R} 2$ & R3 & $\mathrm{R} 4$ & R5 & $\mathrm{R} 1$ & $\mathrm{R} 2$ & R3 & R4 & R5 \\
\hline Sealapex & 3 & 4 & 4 & 2 & 3 & 2 & 2 & 2 & 3 & 3 & 3 & 4 & 2 & 2 & 2 \\
\hline Sealapex/ZnO & 4 & 3 & 4 & 3 & 4 & 2 & 2 & 2 & 2 & 3 & 3 & 2 & 2 & 2 & 2 \\
\hline Sealer 26 & 3 & 4 & 3 & 4 & 4 & 3 & 3 & 3 & 4 & 3 & 1 & 1 & 2 & 2 & 2 \\
\hline Sealer 26 (thicker) & 4 & 4 & 4 & 4 & 4 & 3 & 4 & 4 & 4 & 3 & 2 & 3 & 2 & 1 & 4 \\
\hline White MTA & 3 & 4 & 4 & 3 & 4 & 1 & 1 & 2 & 1 & 3 & 1 & 1 & 2 & 1 & 2 \\
\hline
\end{tabular}


cells were noted in 3 specimens. No necrosis was seen.

Sealapex with addition of $\mathrm{ZnO}$. Most specimens showed a fibrous connective tissue with a mild inflammation and scarce areas with residual sealer (Fig. 3). Necrosis and foreign-body giant cells were not observed.

Sealer 26. A moderate chronic inflammation was frequently observed, mainly formed by lymphocytes and macrophages, with presence of residual sealer. Although necrosis was not observed, foreign-body giant cells were noted in 3 specimens.

Sealer 26 with thicker consistency. Most specimens showed a dense granulation tissue presenting a severe chronic inflammation associated with large

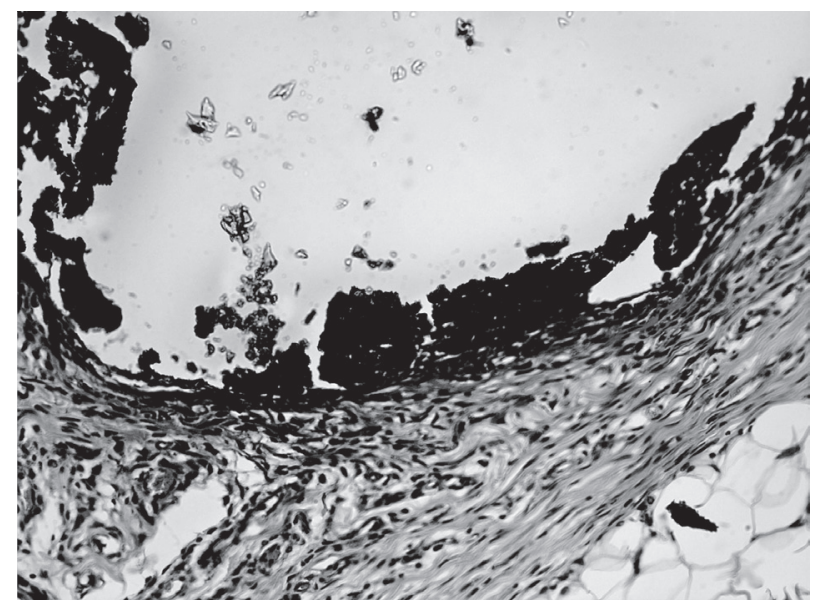

Figure 1. Sealapex with addition of $\mathrm{ZnO}, 7$ days. A moderate chronic inflammation associated with residual material (HE, original magnification, $\times 200$ ).

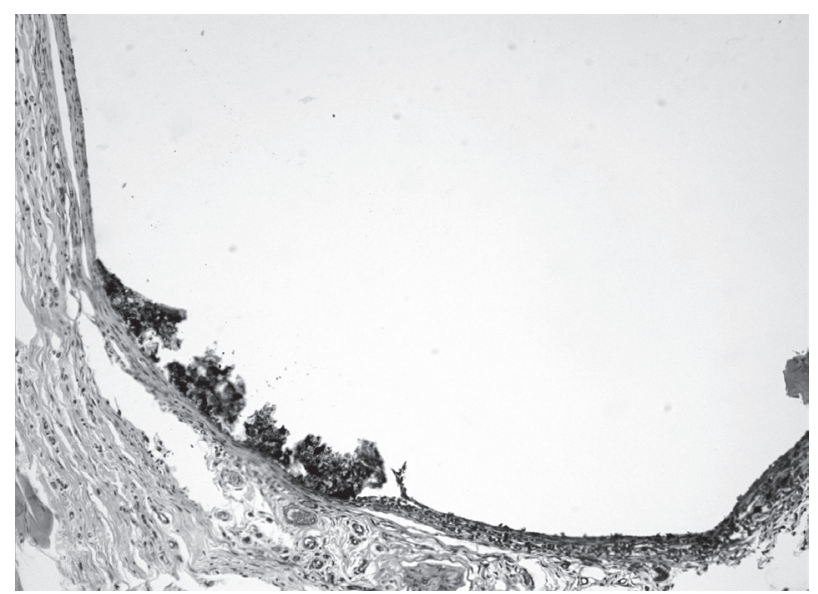

Figure 3. Sealapex with addition of $\mathrm{ZnO}, 21$ days. Slight chronic inflammatory reaction in contact with residual sealer (HE, original magnification, $\times 100)$. amount of foreign-body giant cells and abundant residual sealer (Fig. 4).

White MTA. A fibrous connective tissue without inflammation was often observed. In 1 specimen, foreign-body giant cells were found.

\section{Days}

Sealapex. A mild chronic inflammatory in a fibrous connective tissue was often observed. Most specimens showed large amount of residual sealer.

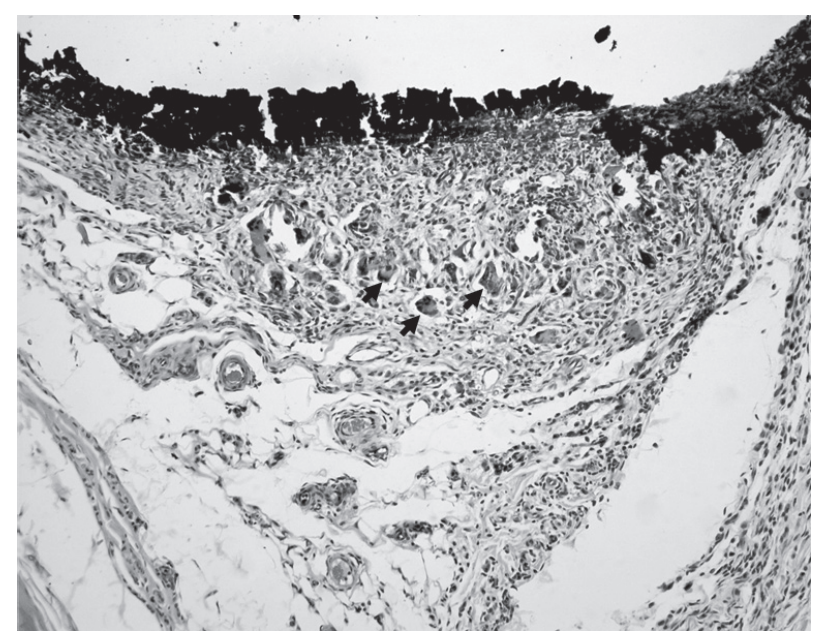

Figure 2. Sealer 26 with thicker consistency, 7 days. Residual sealer associated with severe chronic inflammation and numerous foreign-body multinucleated giant cells (arrows) (HE, original magnification, $\times 100$ ).

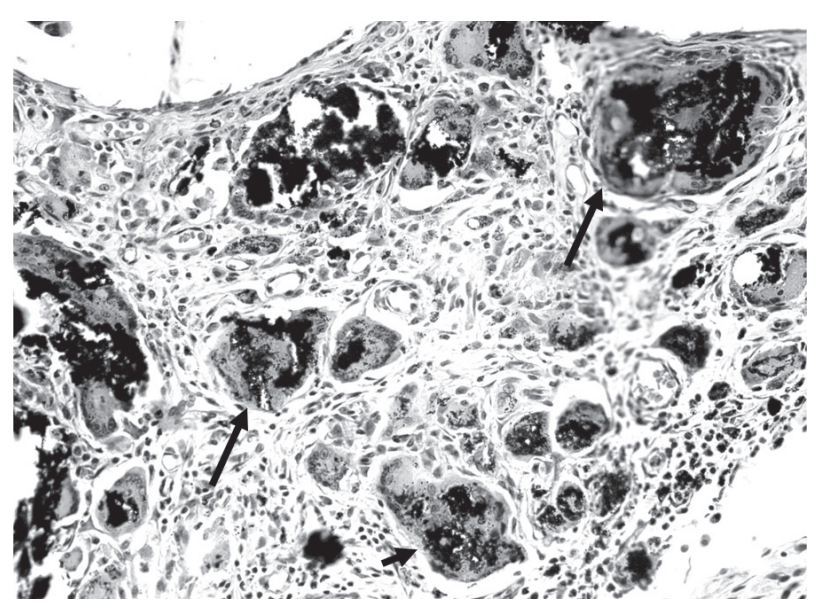

Figure 4. Sealer 26 with thicker consistency, 21 days. Severe chronic inflammatory reaction and several foreign-body giant cells with abundant residual sealer (arrows) (HE, original magnification, $\times 200$ ) . 
Necrosis or foreign-body giant cells were not observed. Sealapex with addition of $\mathrm{ZnO}$. Most specimens presented a mild chronic inflammation in a wellorganized granulation tissue, which showed residual sealer. In 2 specimens, foreign-body giant cells were observed. Necrosis was absent.

Sealer 26. A fibrous connective tissue with small amount of residual material was observed in most specimens, associated with a mild chronic inflammation.

Sealer 26 with thicker consistency. Different inflammatory scores were obtained for this material at this evaluation period. Mild, moderate and severe chronic inflammatory reactions were observed in the specimens, predominantly formed by lymphocytes and macrophages. Foreign-body giant cells were found in 3 specimens and residual sealer was frequently observed. Small foci of necrosis were also noted.

White MTA. A fibrous connective tissue, with few residual sealer and absence of inflammation was the most common finding (Fig. 5). In 1 of these specimens, there was intense hyalinization. In other 2 specimens, there was a mild inflammation mainly composed by lymphocytes and macrophages. Necrosis and foreignbody giant cells were not observed.

\section{Statistical Analysis}

Comparing the scores attributed to inflammatory reaction intensity, no statistically significant differences were observed among the sealers at 7 days $(\mathrm{p}=0.35)$. However, at 21 days, Sealer 26 with thicker consistency

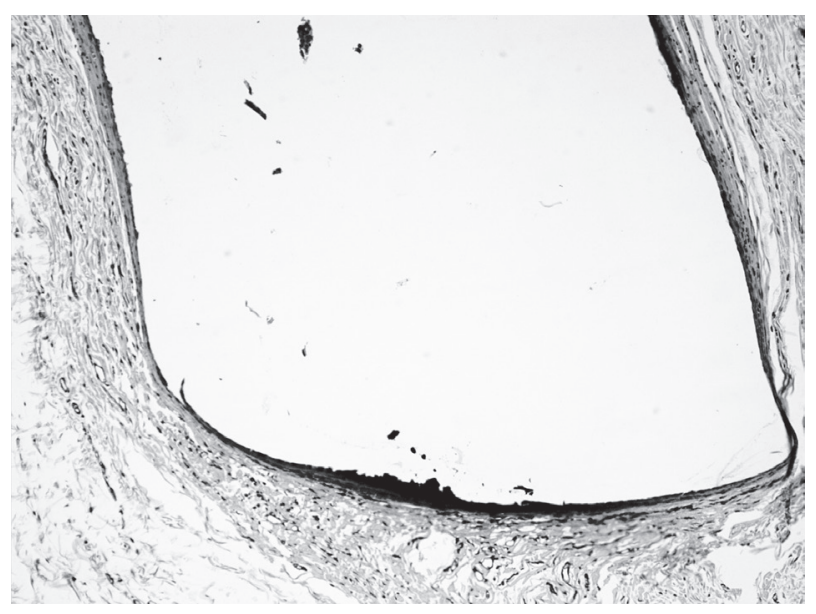

Figure 5. White MTA, 42 days. Fibrous connective tissue without inflammation and with a few amount of residual sealer (HE, original magnification, $\times 100)$. presented the highest inflammatory scores $(\mathrm{p}=0.004)$. Sealer 26 presented higher inflammatory scores than White MTA. At 42 days, the sealers exhibited similar inflammatory scores $(p=0.08)$. Sealapex with incorporation of $\mathrm{ZnO}(\mathrm{p}=0.008)$, Sealer $26(\mathrm{p}=0.004)$, Sealer 26 with thicker consistency $(\mathrm{p}=0.02)$ and White MTA $(p=0.008)$ presented a statistically significant decrease of the inflammatory scores over time, which was not observed for Sealapex.

\section{DISCUSSION}

Knowledge of the irritating potential of any dental material to the living tissues is essential, because any toxic components present in these materials could cause irritation, degeneration or tissue necrosis (9). In any root-end filling system, the sealer will be in close contact with the periapical tissues, with a greater probability of causing some degree of tissue irritation.

In this study, after 7 days, all sealers induced similar inflammatory reactions in the rat connective tissue, with most specimens showing moderate to severe chronic inflammation and presence of foreign-body multinucleated giant cells. Similar results were found by Veloso et al. (10) for Sealapex. However, some authors have observed that Sealapex induced a mild to moderate inflammation in the subcutaneous tissue after 7 days $(11,12)$. Studies on the biocompatibility of Sealapex with addition of $\mathrm{ZnO}$ are very scarce, with few data in the literature. Regarding white MTA, Gomes Filho et al. (5) observed a mild to moderate chronic inflammatory reaction after 7 days of implantation of the sealer in rat subcutaneous tissues.

After 21 days, the reactions caused by conventional Sealapex and Sealapex with addition of $\mathrm{ZnO}$ were similar, with predominance of mild inflammation. Other studies also observed that the Sealapex presents good biological properties $(10,12-14)$. In this same period, most specimens filled with Sealer 26 presented moderate chronic inflammation, whereas Sealer 26 with thicker consistency induced a severe chronic inflammation in most specimens, with scores showing significant differences. For this later material, several foreignbody multinucleated giant cells with sealer particles were frequently observed. Although Barbosa et al. (15) reported low toxicity of Sealer 26, Veloso et al. (10) also observed a more severe inflammatory reaction associated with this sealer, in the same way as observed in the present study. Moreover, the greater cytotoxicity 
of Sealer 26 is probably due to the components of the epoxy resin (16). White MTA presented predominantly a fibrous tissue without inflammation after 21 days, similar to observed by other authors $(1,5,17)$. However, 1 specimen showed mild chronic inflammation with presence of foreign-body multinucleated giant cells.

Along 42 days after implantation of the tubes containing the sealers, Sealapex, Sealapex with addition of $\mathrm{ZnO}$ and Sealer 26 presented mild inflammatory reactions, but there was still the presence of foreignbody giant cells. The combination Sealapex and $\mathrm{ZnO}$ apparently did not alter the biological properties of the sealer. Although Tanomaru Filho et al. (2) used a distinct study model, those authors observed an adequate periapical bone repair when Sealapex with addition of $\mathrm{ZnO}$ was used as root-end filling sealer in dogs. These results probably are related to the $\mathrm{ZnO}$, which presents low tissue irritation and induce a good tissue repair. Comparing the Sealapex and Sealer 26, no statistically significant difference was observed after 42 days, in contrast with the findings of Veloso et al. (10), who found more irritability of Sealer 26 when compared with Sealapex.

The presence of foreign-body multinucleated giant cells at 42 days reveals that these sealers have the ability to form a foreign body granulomatous reaction, probably due to greater difficulty in digestion of these materials by cells of macrophage origin. This fact is important, particularly in orthograde or retrograde fillings because the presence of foreign-body granulomas can contribute for the persistence of a periapical periodontitis (18).

In the group of white MTA, after 42 days, most specimens did not present inflammatory reaction or foreign-body granulomatous inflammatory reaction, in the same way as observed in other studies $(1,5,17)$. Some authors have reported that white MTA induced satisfactory periapical repair when used in retrograde fillings in dogs $(2,6)$.

At 42 days, Sealer 26 with thicker consistency induced different inflammatory reactions, ranging from the absence of inflammation to severe chronic inflammation, with frequent presence of foreignbody giant cells. Considering the descriptive analysis, Sealer 26 with thicker consistency presented higher inflammatory scores than Sealer 26, probably because of its greater powder-resin ratio, increasing the amount of bismuth oxide, hydroxymethylene tetramin and titanium dioxide, which may be irritants to live tissues.
However, the use of Sealer 26 with thicker consistency for retrograde filling in dogs showed a good periapical repair $(2,19)$.

Analyzing each sealer over time, only Sealapex did not present significant decrease of the inflammatory scores over time. Even though this finding did not indicate more intense inflammatory reactions, it can influence the selection of the sealer for use in orthograde or retrograde fillings. However, the results from previous studies are conflicting. Zmener et al. (20) observed increase of the inflammatory reaction intensity associated with this sealer along the time, whereas Silveira et al. (11) noted that the inflammation decreased over time.

In contrast to the present study, histological analysis of the periapical region in dogs and in subcutaneous tissues of rats reveal that all these sealers and combinations stimulated mineralized tissue deposition $(2,5,17)$. Nevertheless, the review of available data, mainly that from studies on subcutaneous tissues, did not show the unequivocal formation of mineralized tissue and the positivity indicated by the Von Kossa staining seem to represent calcium ions released from the sealers $(5,17)$.

According to the results obtained in this study, the findings regarding the biocompatibility of these sealers are most consistent for MTA, which presented the lowest inflammatory scores, with good biological behavior. However, the biological properties of other studied sealers, even though often used in retrograde fillings, are yet to be elucidated. Further studies should be performed in order to determine their biocompatibility profile.

\section{RESUMO}

O objetivo deste estudo foi avaliar a biocompatibilidade de cimentos utilizados em cirurgia apical, em tecidos subcutâneos de ratos. Tubos de polietileno esterilizados foram preenchidos com os seguintes cimentos: Sealapex, Sealapex acrescido de óxido de zinco, Sealer 26, Sealer 26 espessado (maior proporção pó:resina) e MTA branco. Os tubos foram implantados no dorso de ratos machos e após 7, 21 e 42 dias, os animais foram mortos, obtendo 5 amostras por cimento em cada período analisado. A superfície lateral do tubo foi utilizada como controle negativo. A reação inflamatória em contato com os cimentos foram classificadas como ausente, leve, moderada e severa. Aos 7 dias, todos os cimentos induziram reações inflamatórias similares no tecido conjuntivo dos animais, com a maioria dos espécimes apresentando reação inflamatória crônica de moderada a intensa, com presença de células gigantes multinucleadas. Aos 21 dias, Sealer 26 e Sealer 26 espessado apresentaram reação inflamatória mais intensa ( $p=0,004)$, enquanto após 42 dias, a reação inflamatória variou de ausente a leve, com resultados estatisticamente semelhantes para 
ambos materiais ( $p=0,08)$. Com exceção do grupo MTA, todos os cimentos apresentavam reação granulomatosa de corpo estranho após 42 dias. Todos os grupos, exceto o Sealapex, apresentaram redução estatisticamente significante dos índices inflamatórios ao longo do tempo. Conclui-se que todos os cimentos induziram reação inflamatória de moderada a intensa no período inicial de análise. Entretanto, Sealer 26 e Sealer 26 espessado apresentaram reação inflamatória mais intensa após 21 dias de contato com os tecidos e reação granulomatosa não foi observada no grupo MTA no período final de análise.

\section{REFERENCES}

1. Torabinejad M, Parirokh M. Mineral trioxide aggregate: a comprehensive literature review - Part II: Leakage and biocompatibility investigations. J Endod 2010;36:190-202.

2. Tanomaru-Filho M, Luis MR, Leonardo MR, Tanomaru JM, Silva LA. Evaluation of periapical repair following retrograde filling with different root-end filling materials in dog teeth with periapical lesions. Oral Surg Oral Med Oral Pathol Oral Radiol Endod 2006;102:127-132.

3. Bodrumlu E. Biocompatibility of retrograde root filling materials: a review. Aust Endod J 2008;34:30-35.

4. Campos-Pinto MMD, Oliveira DA, Versiani MA, Silva-Sousa YTC, Sousa-Neto MD, da Cruz Perez DE. Assessment of the biocompatibility of Epiphany root canal sealer in rat subcutaneous tissues. Oral Surg Oral Med Oral Pathol Oral Radiol Endod 2008; 105:e77-e81.

5. Gomes-Filho JE, Watanabe S, Bernabé PF, De Moraes Costa MT. A mineral trioxide aggregate sealer stimulated mineralization. $\mathrm{J}$ Endod 2009;35:256-260.

6. Torabinejad M, Hong CU, Pitt Ford TR, Kaiawasam SP. Tissue reaction to implanted Super-EBA and mineral trioxide aggregate in the mandible of guinea pigs: a preliminary report. J Endod 1995;21:569-571.

7. Sumer M, Muglali M, Bodrumlu E, Guvenc T. Reactions of connective tissue to amalgam, intermediate restorative material, mineral trioxide aggregate, and mineral trioxide aggregate mixed with chlorhexidine. J Endod 2006;32:1094-1096.

8. Herrero de Morais CA, Bernardinelli N, Garcia RB, Duarte MAH, Guerisoli DMZ. Evaluation of tissue response to MTA and Portland cement with iodoform. Oral Surg Oral Med Oral Pathol Oral Radiol Endod 2006;102:417-421.

9. Huang TH, Yang CC, Ding SJ, Yan M, Chou MY, Kao CT.
Biocompatibility of human osteosarcoma cells to root-end filling materials. J Biomed Mater Res 2005;72:140-145.

10. Veloso HH, Santos RA, Araújo TP, Leonardi DP, Baratto Filho F. Histological analysis of the biocompatibility of three different calcium hydroxide-based root canal sealers. J Appl Oral Sci 2006;14:376-381.

11. Silveira CMM, Pinto SCC, Zedebski RAM, Santos FA, Pilatti GL. Biocompatibility of four root canal sealers: a histopathological evaluation in rat subcutaneous connective tissue. Braz Dent $\mathbf{J}$ 2011;21:21-27.

12. Economides N, Kotsaki-Kovatsi VP, Poulopoulos A, Kolokuris I, Rozos G, Shore R. Experimental study of the biocompatibility of four root canal sealers and their influence on the zinc and calcium content several tissues. J Endod 1995;21:122-127.

13. Mittal M, Chandra S, Chandra S. Comparative tissue toxicity evaluation of four endodontic sealers. J Endod 1995;21:622-624.

14. Gomes-Filho JE, Bernabé PFE, Nery MJ, Otoboni-Filho JA, Dezan-Junior E, Costa MMTM, et al.. Reaction of rat connective tissue to a new calcium hydroxide based sealer. Oral Med Oral Pathol Oral Radiol Endod 2008;106:e71-e76.

15. Barbosa SV, Araki K, Spangberg LS. Cytotoxicity of some modified root canal sealers and their leachable components. Oral Surg Oral Med Oral Pathol 1993;75:357-361.

16. Queiroz CE, Soares JA, Leonardo RT, Carlos IZ, Dinelli W. Evaluation of cytotoxicity of two endodontic cements in a macrophage culture. J Appl Oral Sci 2005;13:237-242.

17. Gomes-Filho JE, Rodrigues G, Watanabe S, Estrada Bernabé PF, Lodi CS, Gomes AC, et al.. Evaluation of the tissue reaction to fast endodontic cement (CER) and Angelus MTA. J Endod 2009;35:1377-1380.

18. Nair PNR. Pathogenesis of periapical periodontitis and the causes of endodontic failures. Crit Rev Oral Biol Med 2004;15:348-381

19. Barbosa HG, Holland R, Souza V, Dezan EJ, Bernabé PFE, Otoboni JA, et al.. Healing process of dog teeth after post space preparation and exposition of the filling material to the oral environment. Braz Dent J 2003;14:103-108.

20. Zmener O, Gugliemotti MB, Cabrini RL. Tissue response to an experimental calcium hydroxide-based endodontic sealer: a quantitative study in subcutaneous connective tissue of the rat. Endod Dent Traumatol 1990;6:66-72.

Received December 22, 2010 Accepted May 15, 2011 